\title{
A CASE STUDY ON THE STUDENTS AND TEACHERS' PERCEPTIONS ON THE USE OF ENGLISH AS A MEDIUM OF INSTRUCTION AND TEACHERS PROFESSIONAL COMPETENCIES AT SMP NEGERI 1 DENPASAR
}

\author{
Sudiatmika , I K. \\ Program Studi Pendidikan Bahasa Inggris, Program Pascasarjana \\ Universitas Pendidikan Ganesha \\ Singaraja, Indonesia \\ e-mail: sudiatmika_eed@yahoo.com \\ Nitiasih, P. K. \\ Program Studi pendidikan Bahasa Inggris, Program Pascasarjana \\ Universitas Pendidikan Ganesha \\ Singaraja, Indonesia \\ e-mail: titiekjegeg@gmail.com \\ Suarnajaya, I. W. \\ Program Studi pendidikan Bahasa Inggris, Program Pascasarjana \\ Universitas Pendidikan Ganesha \\ Singaraja, Indonesia \\ e-mail:w_suarna@yahoo.com
}

\begin{abstract}
This study aims at investigating the students and hard science teachers' perceptions on the use of English as the language of instruction, the frequency of English used as the medium of instruction by hard science teachers, and the hard science teachers' professional competences at SMP Negeri 1 Denpasar in science classes at RSBI (Rintisan Sekolah Bertaraf Internasional). The subjects of this study were the students and hard science teachers of SMP Negeri 1 Denpasar. The data on the frequency of English used by the teachers were gathered by recording the instructional process. The students and teachers' perceptions and the teachers' professional competencies were gathered using questionnaire and interview. The obtained data were then analyzed descriptively. The findings of the study showed that the students and hard science teachers of SMP Negeri 1 Denpasar have positive perceptions toward English. The frequency of the use of English as the medium of instruction varies. It showed that the mathematics teacher had a high frequency of English use. While the frequency of biology and a physics teacher in using English was considerably very low. The data also revealed that the hard science teachers had implemented professional competencies covering pedagogy, personal, social, and professional competencies.
\end{abstract}

Keywords: Hard science teachers, Bilingual classes, Perception, Frequency, Professional competencies.

\section{INTRODUCTION}

In planning, conducting, and assessing or evaluating an education, "Adaptation" is an important aspect to be considered. Adaptation means adjustment among education planning, conduction, and the social factors where the education plan is conducted. Universally, education must focus on the preparation of facing globalization era. Olssen, Codd, and O'Neill (2004) in their book entitle "Education Policy: Globalization, Citizenship \& Democracy" states that globalization is not a new phenomenon but it becomes more complex and spreads more widely with (the entry of sophisticated technologies as well as the expansion of global markets. 
In line with the expansion of global market, global competition grows rapidly too, bringing effect to each country all over the world that tries to change itself so it can prove its international influence. In this globalization era, people live in the world of rapid changes marked by economic crisis, flood of information through multimedia, fast traffic of modern technology, and an implementation of a regional autonomy. Many people are forced to face many rapid changes in every single piece of life in this era. Therefore, a good qualification is needed in order to take appropriate action in facing those changes. But, the most important means to be well qualified in facing the changes is education quality.

Today, education in Indonesia has been doing a prominent innovation concerning on school curriculum. The innovation involves the method of learning, the way of thinking, and the evaluation technique. Referring to this problem, The National Education Department decided to change the previous curriculum Competence Level Based Curriculum (C LBC) with the new one called School Level Based Curriculum (SLBC) Kurikulum Tingkat Satuan Pendidikan (KTSP). Based on Badan Standar Nasional Pendidikan, (2006) Curriculum is defined as a set of plans and rules about goals, contents, and learning materials as well as the way of using it as guidance for implementation of learning activities aimed at a specific goal. The specific goal covers national education goal as well as the compatibility with the uniqueness, condition and potential of the area.

Besides the changing of curriculum that has been done, Indonesian educational policy maker also considers it necessary to react proactively to the global competition. In order to achieve it, the educational policy maker is focusing on the development of the national education on three policies. Those policies are (1) the expanding and even distribution of education access, (2) the improvement of quality, relevancy, and competitiveness of education, and (3) the reinforcement of the management, accountability, and public image (Depdiknas, 2006). Various efforts and policies have been done to achieve those three pillars of education. For example, much training is held, instructional media and breakthrough efforts are also optimized.

Considering the importance of education, Indonesian government has applied many ways to improve the educational quality. One of them is by implementing a new educational policy called Sekolah Bertaraf Internasional, one of the breakthrough efforts done by the government. It is a new and innovative policy in education recently published by the government (UUSPN 20/2003, pasal 50 ayat 3). This program is expected to improve the quality of national education to enhance the competitiveness among other countries. In other words, it can be said that SBI imitates the instruction implemented in developed countries trying to accommodate the students' potential to achieve the targeted standard competency in ordinary school. In developed country, potential and talented students are categorized into exclusive class called GATS (Gifted and Talented Students).

There are a number of characteristics of Sekolah Bertaraf International (SBI), such as:

\section{An independent school (Sekolah Kategori Mandiri)}

Sekolah Kategori Mandiri is a categorization done by the Indonesian government toward the implementation of the eight national education standards (including standards of content, process, graduates' competence, teachers and school staffs, facilities, school management, funding, and evaluation) and the implementation of Satuan Kredit Semester (SKS). That categorization is one effort of the education quality mapping on the achievement of national education standards in improving the quality of education in Indonesia.

\section{The school proceeds the curriculum based on Permendiknas No. 22, 23, and 24, 2006}

Permendiknas No. 22, 2006, gives details about the standard of content. It includes the basic form and structure of curriculum becoming the guideline in constructing school based curriculum; students' work load in primary and secondary school; school based curriculum which will be developed by the school in accordance with the module of constructing curriculum; and the educational calendar for the education implementation in both primary and secondary schools. On the other hands, Permendiknas No. 23, 2006, explains about the standard of graduates' competence. It includes the minimal standard of pass for primary and secondary schools students, minimal standard competency for each subject group, and for each subject. That standard is used as the evaluation guideline in deciding the students' state. The implementation of Permendiknas No. 22 and No. 23 year 2006 is governed in detail in Permendiknas No. 24 including the function of departments which are in charge in educational policy (Depdiknas, 2006). 
The availability of educators who are able to teach English as the language of instruction (bilingual instruction) in Math, Chemistry, Physic, and Biology (hard science) on the first phase, and other subject (soft science) on the following phase.

\section{The availability of sufficient high quality media of instructional process.}

The availability of sufficient fund in developing RSBI (provided by the center government and the local government). Regarding to the explanations of the characteristics of RSBI above, there are several characteristics of RSBI that need to be highlighted, one of them is the use of English as a media or language of instruction besides bahasa Indonesia as national language. Another characteristic is the use of national-plus curriculum that means beside the use of national curriculum the schools also use another curriculum adapted from another country that is oriented on international curriculum. Therefore, the students who are chosen in this program are the students who have above level ability. These students will be taught exclusively, for instance, the use of Bahasa Indonesia and English as media or language of instruction (Bilingual teaching system) that is oriented on the high achievement of competency. This learning and teaching system absolutely need teachers and students who have good ability in using English.

In RSBI, primarily, the demand of using English must be fulfilled by the "hard science" teachers. Hard science is colloquial terms often used when comparing fields of academic research or scholarship, with "hard" meaning perceived as being more scientific, rigorous, or accurate. For example, fields of the natural sciences or physical sciences are often described as hard in contrast to soft social sciences (http://en.wikipedia.org/wiki/Hard and soft science). The hard sciences are characterized as relying on experimental, empirical, quantifiable data or the scientific method, and focusing on accuracy and objectivity. They are expected to master English as the medium of instruction since the government regulation affirms that in RSBI the hard science instruction, in this case including mathematics, physics, chemistry, and biology must be bilingual.

However, based on pre-observation done at SMP Negeri 1 Denpasar where the school has been labelled as RSBI since 2007, the educational backgrounds of hard science teachers are mostly national educational program, in which the education is all in Bahasa Indonesia. The teachers had learnt English at least in their high school years and their first semester at the university. They did not have the opportunity to learn English intensively so that they could not use English to communicate appropriately.

Concerning the phenomenon stated above, this research is intended to investigate the implementation of RSBI especially of using English or being bilingual in teaching and learning sciences. It is essential for this research to explore the students and teachers' perception on the use of English as the medium of instruction in the bilingual classes, the frequency of the teachers' use of English as the medium of instruction, and hard science teachers' professional competencies at SMP Negeri 1 Denpasar. It is very essential to know the real condition, problems and challenges that might occur from the policy applied to get clearer picture on what have been happening in the school. Besides, this study is necessary regarding the possibilities to formulate some recommendations for the policy maker based on the gaining result concerning with the students and teachers' perception, and the frequency of the teachers' use of English as the medium of instruction in the bilingual class on $R S B I$.

In an attempt to ascertain the students and teachers' perception on the use of English as the medium of instruction in the bilingual classes, the frequency of the teachers' use of English as the medium of instruction, and the teachers' professional competencies outlined in the introduction, the following research questions are addressed: 1) What are the hard science teachers' perceptions on the use of English as the medium of instruction in the science classes at SMP Negeri 1 Denpasar? 2) What are the students' perceptions on the use of English as the medium of instruction in the science classes at SMP Negeri 1 Denpasar? 3) What is the frequency of the hard science teachers' use of English as the medium of instruction in the science classes at SMP Negeri 1 Denpasar? 4) How are the hard science teachers' professional competencies at SMP Negeri 1 Denpasar?

Referring to the research questions previously mentioned, the objectives of this study can be asserted as follows: This study aims at giving a description of students and teachers' perceptions on the use of English as the medium of instruction in the science classes at SMP Negeri 1 Denpasar, giving a description of the frequency of hard science teachers' use of English as the medium of 
instruction in science classes at SMP Negeri 1 Denpasar, and giving description upon the hard science teachers' professional competencies at SMP Negeri 1 Denpasar.

This study was a qualitative study involving descriptive analysis. Qualitative approach is an approach in which the description of observation is not ordinarily expressed in quantitative terms, it is not suggested that numerical measures are not used, but that the other means of description are emphasized (Best, 1981). Moreover, a qualitative analysis can be classified into descriptive analysis. It aims to make description about a situation or events (Suryabrata, 1983, in Erayani, 2003:27). Suryabrata also defined clearly that the method of qualitative descriptive analysis is becoming the way to do analysis from a wide scale to smaller points and then it is clarified in a written form trough some descriptions according to factual data and finally concluded.

Qualitative approach in this study was used to find out the students and teachers' perception on the use of English as the medium of instruction in the bilingual classes, the frequency of the teachers' use of English as the medium of instruction. Besides, the qualitative approach was intended to describe the hard science teachers' professional competencies at SMP Negeri 1 Denpasar. After that, all of the result of the data from the calculation were analyzed and described qualitatively.

\section{METHOD}

Classroom observation technique was used to collect the data that were related to human being behavior, working process, and natural signs (Sugiyono, 2006). Observation is a primary source of data in qualitative research (Merriam, 1998; Silverman, 2005). This research needed observation as supporting data to see whether English was used in sciences and math class as an instrument of communication. Since this research was trying to investigate the phenomenon of the use of English in teaching sciences and math in the classroom, then did the classroom observation was appropriate.

To do an accurate classroom observation, the learning and teaching process were observed when sciences and math teachers were teaching their subjects to the students. Checklist and field notes were used in doing classroom observation.

The second method was recording the data by using recorder (digital camera). The data obtained is from the teachers and students when they had bilingual class. Another method used was interview. Oxford English Dictionary (1984:75) states that interview is a meeting of people face to face, especially for consultation. The aim of doing an interview was to gain information about a particular thing or issue from the interviewee.

According to Santiago (2009) there are three types of interview that can be conducted when carrying out a research project. Those are structured, semi-structured, and unstructured interviews.

Structured interviews require adherence to a very particular set of rules. Each question that is outlined should be read word by word by the researcher without any deviation from the protocol. In some cases, the interviewer is also required to show consistency in behavior across all interviews. This includes bodily posture, facial expressions, and emotional affect. Reactions to participant responses should be kept to a minimum or avoided entirely.

Semi-structured interviews are a bit more relaxed than structured interviews. While researchers using this type are still expected to cover every question in the protocol, they have some wiggle room to explore participant's responses by asking for clarification or additional information. Interviewers also have the freedom to be more friendly and sociable.

Semi-structured interviews are most often used in qualitative studies. The style is most useful when an interviewer is investigating a topic that is very personal to participants.

Structured interviews are the type used most often by quantitative researchers. The style is most useful when looking for very specific information. The benefits are that it keeps the data concise and reduces researcher bias.

To interview the participants of the research, the researcher used semi-structured style of interviewing to interview the subject of the study. Interviews in this study were important means of helping participant articulate their options or perceptions about the use of English in teaching and learning sciences and math and their feelings being bilingual or international class. Interviews in this study also play an important role to enable the research to check the honesty of the subject of the study. 


\section{FINDINGS AND DISCUSSION}

Based on the questionnaire, the hard science teachers of SMP Negeri 1 Denpasar expressed positive point of view in correlation about the perception towards English. In brief, as the statements stated in the questionnaire, they all agreed that everyone has special competence to learn English. They even strongly agreed about the statement that English is not difficult language to be learnt therefore they felt that they could speak English well and felt happy to do so. While most of the teachers also thought that it is important to know spoken English's culture in order to speak it well, therefore they always learn English especially learning vocabulary, a lot of practicing and drilling. The questionnaire also revealed that most of the hard science teachers never felt ashamed when they speak English to others.

Another fact also revealed that most of the students of SMP Negeri 1 Denpasar expressed positive point of view toward the use of English as the medium of instruction, it was supported by some statements such as: the students felt happy to study science by using two languages (English and Bahasa Indonesia), the students were capable of joining science by using two languages, and the students could respond well the teachers' explanation while explaining the material. The questionnaire also revealed that every student agreed that they could speak English well. Some of the students even strongly agreed with the statement that the students believed that they could speak English well. They even strongly agreed about the statement that English is not difficult language to be learnt. Therefore they felt that they could speak English well and felt happy to do so.

Another finding showed that the hard science teachers produced different frequency of English use. Within the process of collecting the data, it was recorded 277 utterances with 74 of them were utterances in English. The following are the proportion of the total amount of the teacher's utterances and the amount of the English utterances used by the teacher as language of instructions.

The following are the proportion of the total amount of the teacher's utterances and the amount of the English utterances used by the teacher as language of instructions.

Table 1. Percentage of the Utterances Employed by Each Hard Science Teacher

\begin{tabular}{|c|c|c|c|c|c|}
\hline No. & Teacher & $\begin{array}{l}\text { Percentage } \\
\text { of English } \\
\text { Utterance }\end{array}$ & $\begin{array}{l}\text { The } \\
\text { amount of } \\
\text { utterances } \\
\text { in Bahasa }\end{array}$ & $\begin{array}{l}\text { Percentage } \\
\text { of the } \\
\text { combination } \\
\text { between } \\
\text { utterance in } \\
\text { English and } \\
\text { bahasa } \\
\text { Indonesia }\end{array}$ & Total \\
\hline 1. & Mathematics & $84.50 \%$ & $9.85 \%$ & $5.63 \%$ & $100 \%$ \\
\hline 2. & Biology & $13.72 \%$ & $62.74 \%$ & $23.52 \%$ & $100 \%$ \\
\hline 3. & Physics & $0 \%$ & $98.07 \%$ & $1.92 \%$ & $100 \%$ \\
\hline
\end{tabular}

Table 1 shows that some of the hard sciences teachers are rarely use English as a language of instruction in their bilingual class. The table above shows that $84.50 \%$ of the language instruction used by the mathematics teacher in bilingual class was in English, with $9.85 \%$ was in Bahasa, and the combination between English and Bahasa Indonesia was $5.63 \%$. Biology teacher produced $13.72 \%$ English utterances, $62.74 \%$ utterances in Bahasa and $0.23 \%$ can be considered as utterances of combination between English and Bahasa. At last is Physic which employed $0 \%$ of English as the language instruction, $98.07 \%$ of utterances in Bahasa, and $1.92 \%$ combination utterances. The total percentage of the use of English as a language applied by the hard science teacher is $0 \%$ from the total 104 utterances. Now based on the score interval provided above, it can be concluded that the 
frequency of English use is very low. The following graph illustrated the percentage of all types of the utterances employed by the hard science teachers.

The hard science teachers at SMP Negeri 1 Denpasar had already done the professional competencies covering pedagogy, personal, social, and professional competency.

There were a number of efforts that had been done by the hard science teachers for pedagogy competency like: Conducting research, using various teaching media, using various teaching techniques and model, reading books, articles and journals about science, participating in scientific forum, the use of learning and teaching facilities, and conducting assessment/evaluation.

For personal competency the hard science teachers had done some efforts such as accepting and giving constructive critics and suggestion from peers, being discipline by coming to the school and the classroom on time, and following religious activities at school. Fortunately, in pursuing this competency the hard science teachers did not find any difficulties.

Based on the finding of the study, the hard science teachers at SMP Negeri 1 Denpasar had implemented the social competency theory stated previously. The hard science teachers were very friendly, open-ended, and helpful to the students who found any difficulties from the subject. They also interlaced a good relationship to the other teachers. Besides, in improving the social competency the teachers also participated in scientific forums, professional community and organization, and conducting discussion with peers.

Professional competence is a basic ability of educator. They will be called professional, if they are able to master the skill theoretically and practically in the process of teaching. This competence refers to theoretical ability practical. In detail, professional ability can be described as follows: (1) deep understanding of subject matter, (2) deep understanding of standards and bases competencies, (3) developing subject content, (4) developing their own professionalism, and (5) using information technology for self-improvement.

The hard science teachers had implemented the professional competency mentioned above, they tried to read some books, articles, journal related to science. They also used information and technology for self-development and conducting research. Becoming professional teachers they have to master their subject matter well and have to follow the development of technology and information.

\section{CONCLUSION AND SUGGESTION}

As stated in the previous chapter, the study was conducted to examine the students and teachers' perceptions on the use of English as the medium of instruction in the science class at SMP Negeri 1 Denpasar, (2) Investigating the frequency of English used as the medium of instruction on hard science teachers at SMP Negeri 1 Denpasar, and (3) Describing the hard science teachers' professional competencies at SMP Negeri 1 Denpasar.

The data were mainly collected through classroom observation which took place for about three weeks. During the observation, the researcher applied recording, interview and distributing questionnaires to gather data to answer the research questions. The result of the questionnaire analysis described that generally the students and the hard science teachers of SMP Negeri 1 Denpasar had positive perception toward the use of English as the language of instruction in the science classes. It was also found that the English use frequency of the hard science teachers of SMP Negeri 1 Denpasar was varied. The mathematic teacher's frequency of using English was considerably high. On the other hand, the frequencies of English use of physic and biology teacher were considerably very low. At last, the physics teacher showed a low category toward the frequency of English use in teaching and learning process. An analysis of the findings found that the different frequency of English use in the hard science classes was caused by some factors, namely, the school policy toward the teacher's use of English in bilingual class, to have a good understanding of the students the use of Indonesia should be dominated, the RSBI policy had not been implemented.

On the other hand, the hard science teachers had implemented the professional development covering, pedagogy, personal, social, and professional pedagogy. For the pedagogy competency the teacher had conducted research, used various teaching media, use various teaching techniques and model, read books, articles and journals about science, participated in scientific forum, the use of learning and teaching facilities, and conducted assessment/evaluation. The personal competency, the hard science teachers did a good action by accepting and giving constructive critics and suggestion 
from peers, being discipline by coming to the school and the classroom on time, and following religious activities at school. In social competency, the hard science teachers participated in scientific forums, professional community and organization, and conducting discussion with peers. In professional pedagogy, they read some books, articles, journal related to science. They also used information and technology for self-development and conducting research. Becoming professional teachers they have to master their subject matter well and have to follow the development of technology and information.

After compiling the findings of the study, some recommendations could be drawn. It is recommended that the hard science teachers should improve their competence and proficiency of the hard science teachers' use of English, in the classroom. It can be actualized through the optimizing of the facilities which have been provided to improve the teachers' use of English such as ICT basedequipment, private English courses or the course facilitated by the fellow English teacher in the school (MGMP Bahasa Inggris), TOEFL and TOEIC test, and the role of English tutor from higher education institution. Therefore they can fulfill the requirement of ideal bilingual teachers of $S B I$.

The school, through the committee of $S B I$, should be more aware toward the real condition of the teachers' personal or the class situation and other obstacles faced by the teachers in using English in the bilingual class, especially for hard science. It is essential in the correlation in choosing appropriate method to overcome the challenges of the implementation of bilingual education in $S B I$.

Indonesian government as the policy maker should not only decide the policy of for the implementation of $S B I$, but also need to examine the regulation and at the same time evaluating the program continuously. This is ensuring the feedback for both government and the school itself for the sake of improving the quality of $S B I$ program.

School and committee are suggested to provide budget for more new books, articles, and journals of science and education, especially books, articles and journals for the hard science teachers.

Finally, for further research, it is recommended to do more analysis on the effect of hard science teachers' use of English in the bilingual classes toward the students' achievement.

\section{REFERENCE}

------_------. 2005. Buku Pedoman Studi Institut keguruan dan Ilmu Pendidikan Negeri Singaraja Fakultas Pendidikan Bahasa dan Seni Tahun 2002 Edisi Revisi. Singaraja: IKIP Negeri Singaraja.

2007. Panduan Penyelenggaraan Rintisan SMA Bertaraf Internasional. Direktorat Pendidikan Nasional Jenderal Manajemen Pendidikan Dasar dan Menengah Direktorat Pembinaan Sekolah Menengah Atas.

2007. Sistem Penyelenggaraan Sekolah Bertaraf Internasional (SBI) untuk Pendidikan

Dasar dan Menengah. Jakarta: Departemen pendidikan Nasional Direktorat Jenderal Manajemen Pendidikan dasar dan Menengah.

------_------. 2008. Rubrik Info Pendidikan Dinas Kabupaten Probolinggo (http://www.dispendikkabprob.org/cetak.php?)

2009. Bilingual Education Consortium guidebook. Macomb Intermediate School District (http://www.google.com/search?US_education_documen_English_bilingual_education)

2009. Hymes' Communicative Competence and Communicative Language Teaching.( http://en.wikipedia.org/wiki/Communicative_competence)

$\begin{array}{ccccc}\text { (http://www.nabe.org/education/index.html/what is bilingual education) } & \text { Bilingual Education. }\end{array}$

----------. 2009. http://en.wikipedia.org/wiki/Hard and soft science 


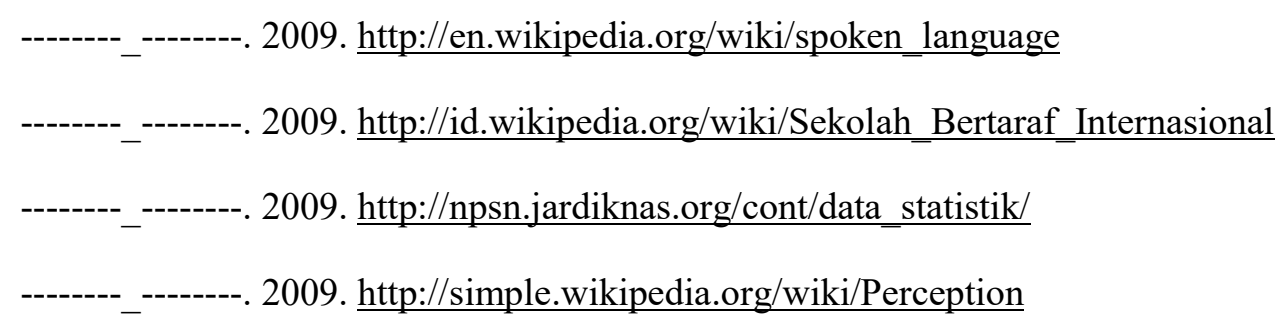

Best, J. W.1981. Research in Education, New Jersey. Prentice Hall, Inc.

Codd, Mark Olssen, Anne-Marie O'Neill, John A. 2004. Education Policy: Globalization, Citizenship and Democracy. London, Thousand Oaks, New Delhi: Sage Publications.

Dewi, Putu Sri Ayu Ratna. 2008. The Application of Storytelling Technique Assisted with Series of Pictures to Improve the Second year Students' Oral Competence. Universitas Pendidikan Ganesha, (Unpublished thesis).

Erayani, Sri Ni Made. 2003. Character's Revelation In NH Dini's Novels: An Analysis on the Author's Techniques of Character Revelation. Unpublished thesis IKIP Negeri Singaraja.

Hariyanto. 2009. Pentahapan (Fase) Pengembangan Program Rintisan SMA Bertaraf Internasional (http://www.google.com/search?bilingual teachers English proportion)

Hornby, A. S. 1995. Oxford Advanced learner's Dictionary. New York: Oxford University Press.

Ibrahim, Abd. Syukur. 1986. Analisis Bahasa untuk Pengajaran Bahasa. Surabaya, Indonesia: Usaha Nasional.

Janawi. 2011. Kompetensi Guru, Cintra Guru Profesional. Bandung: Alfabeta

Juniarta, I Gede Edy. 2009. Hard Science Teachers' Use of English in Bilingual Classes at SMA Negeri 1 Denpasar: a Case Study. Ganesha university of Education

Krashen, Stephen. 1997. Why Bilingual Education?(http://English.org/be/krashen.html)

Marskawati, Ni Putu Era. 2006. A Study on Communication Strategies Applied by the Eleventh Grade Students of SMA Laboratorium IKIP Negeri Singaraja for Coping with Communication Problem. Institut Keguruan dan Ilmu Pendidikan Singaraja (Unpublished thesis).

Moeloeng. L.J. 2001. Metodologi Penelitian Kualitatif. Bandung: PT. Remaja Rosdakarya.

Ohno, Atsuko. 2009. Communicative Competence and Communicative Language Teaching. Japan: http://en.wikipedia.org/wiki/Communicative competence

Purnama, Ida Ayu Eka. 2009. Hard Science Teachers' Use Of English In Bilingual Classes At Sma Negeri 4 Denpasar: A Case Study. Unpublished thesis. Universitas Pendidikan Ganesha: Singaraja.

Rismana, Monik Ni Wayan. 2012. Professional development of English teachers in RSBI School in Singaraja. Language Education Concentration, Postgraduate Program, Ganesha University of Education.

Rodgers, Jack C. Richards, and Theodore Stephen. 2001. Approaches and Methods in Language Teaching. Cambridge University Press. 
Santiago, Nadia. 2009. Types of Interview. http://www.examiner.com/scholarly-research-in-sanjose/interview-types-structured-semi-structured-and-unstructured

Sain, Noridah Binti. 2007. Upper Secondary Students' Perception towards Kinesthic Learning Activities Conducted in an English Classroom: an Insight. Malaysia: Universiti Teknologi Malaysia (http://en.wikipedia.org/wiki/Philosophy of perception)

Sumartini, Pande Made. 2008. An Analysis of Leadership Style: A Case Study of a Lecture's Speech Acts at the English Education Department. Universitas Pendidikan Ganesha (Unpublished thesis).

Swasti, Ni Made. 2005. Negotiating Grammar for Meaning. A Study on the "Pidgin" English Expressions Used by the Balinese Vendors at Lovina beach, Bali. IKIP Negeri Singaraja (Unpublished thesis).

Tarhan, Sahika. 2003. Perceptions of students, teachers and parents regarding English-medium instruction at secondary education. Department of Educational Sciences Of Middle East Technical University.

Teja, I Gede Putra. 2008. The Analysis Study of Communication Strategies Used by the Students of Year Eleven IPB 1 of SMA Negeri 1 Ubud. Universitas Pendidikan Ganesha, (Unpublished thesis).

Undang-Undang RI No 14 tahun 2005 tentang Guru dan Dosen

Villegas, Elleonora, \& Reimers. 2003. Teacher professional Development. Paris: International Institute for Education Planning

Vizental, Adriana. 2009. Communication and Communicative Competence. Romania: Aurel Vlaicu University of Arad. 